\title{
An insight to the ecological evaluation index (EEI)
}

\author{
S. Orfanidis ${ }^{\mathrm{a}, *}$, P. Panayotidis ${ }^{\mathrm{b}}$, N. Stamatis ${ }^{\mathrm{a}}$ \\ a National Agricultural Research Foundation, Fisheries Research Institute, \\ 64007 Nea Peramos, Kavala, Greece \\ ${ }^{\mathrm{b}}$ National Center of Marine Research, 16604 Athens, Greece
}

\begin{abstract}
The ecological evaluation index (EEI) was designed to estimate the ecological status of transitional and coastal waters. Marine benthic macrophytes (seaweeds, seagrasses) were used as bioindicators of ecosystem shifts due to anthropogenic stress, from the pristine state with late-successional species (high ecological status class (ESC)) to the degraded state with opportunistic species (bad ESC). The relation of EEI to function and to resilience of the marine ecosystem, and its possibility for comparing and ranking at local, national and international levels are some of its main management implications.

(C) 2003 Elsevier Science Ltd. All rights reserved.
\end{abstract}

Keywords: Water quality; Benthic macrophytes; Functional groups; Ecosystem function; Ecosystem resilience; Water Framework Directive

\section{Introduction}

Central issue in the management of "high" valued transitional and coastal ecosystems (Costanza et al., 1997 ) is the identification of key signals that indicate the degree of human impact or ecological status (Crooks and Turner, 1999). Regarding the ecosystems as dynamic open systems with multiple stable equilibrium states (Holling, 1973) further strengthens the need for ecological assessment, because the restoration of desired states may require drastic and expensive intervention (Maler, 2000).

Communities are often used in ecological assessment as bioindicators of ecological status (Dauer, 1993; Bricker et al., 1999; Gibson et al., 2000; EEC, 2000), because long-term anthropogenic stress is ecologically relevant investigated at community level (Odum, 1985; Crowe et al., 2000). However, the evaluation of the ecological status is often a difficult task

\footnotetext{
* Corresponding author. Fax: +30-5940-22222.

E-mail address: sorfanid@otenet.gr (S. Orfanidis).
}

because of spatial and temporal community variability. A more temporally stable and predictable view of community requires a functional approach (Steneck and Watling, 1982).

Marine benthic macrophytes form the structural base (McRoy and Lloyd, 1981) and behave as ecosystem engineers (sensu Jones et al., 1994) of some of the most productive ecosystems of the world. As photosynthetic sessile organisms, they respond directly to the abiotic and biotic aquatic environment, and thus represent sensitive bioindicators of its changes (for a short-review see Orfanidis et al., 2001).

This paper aims to present an insight to the structure and relevance of the ecological evaluation index (EEI). It has been recently introduced by Orfanidis et al. (2001) for the evaluation of ecological status of transitional and coastal waters in accordance to European Water Framework Directive (WFD) (EEC, 2000). For WFD "ecological status" is an expression of the quality (ecological status class (ESC)) of the structure and functioning of aquatic ecosystems. 


\section{Why and how to use the EEI}

The EEI quantifies shifts in the structure and function of transitional and coastal waters at different spatial and temporal scales by using non-linear and linear relationships.

(a) Shifts in marine ecosystem structure and function are evaluated by classifying marine benthic macrophytes in two ecological state groups (ESGs I, II), representing alternative ecological states, e.g. pristine and degraded. ESG I includes seaweed species with a thick or calcareous thallus, low growth rates and long life cycles (late successionals), whereas the ESG II includes sheet-like and filamentous seaweed species with high growth rates and short life cycles (opportunistic). All seagrasses are included in the first group, whereas Cyanophyceae and species with a coarsely branched thallus are included in the second group. Table 1 shows a provisional list of Greek seaweed genera classified into ESGs.

(b) Spatial and temporal changes of benthic macrophytic communities are identified by seasonal sampling of ecologically uniform non-overlapping permanent-polygons (PPs) or permanent-lines (PLs) of the studied area/coastline (Fig. 1). It is recommended to use PP for well-defined ecosystems, e.g. lagoons, shallow closed bays, and PL for relative open coasts. Sampling can follow a nonaligned block design, in which a sample is located randomly within a representative permanent cell of dimensions $10 \mathrm{~m} \times 10 \mathrm{~m}$. The absolute abundance $(\%)$ of each ESG is estimated by coverage $(\%)$ in each sample. Three samples per season per cell could be an optimum sampling frequency.

(c) To evaluate the ecological status of PPs or PLs the mean absolute abundance (\%) of ESGs I and II sampled in PPs and PLs is non-linearly corresponded to five different ESCs (Table 2). The ESCs are related linearly to the EEI at PP or PL scale (Fig. 2). The surface area of each PP or the length of each PL is multiplied by their EEI and then divided by the sum of surface areas of PPs or lengths of the PLs. The area- or length-weighted values are then summed to estimate the spatial scale weighted EEI and the equivalent ESC (Table 2).
Table 1

Classification of Greek seaweed genera into ESGs

\begin{tabular}{|c|c|}
\hline Genus & ESG \\
\hline Acetabularia & I \\
\hline Acanthophora $^{\mathrm{a}}$ & II \\
\hline Amphiroa & I \\
\hline Anadyomene & I \\
\hline Antithamnion & II \\
\hline Bryopsis & II \\
\hline Calithamnion & II \\
\hline Caulerpa & II \\
\hline Ceramium & II \\
\hline Chaetomorpha & II \\
\hline Champia $^{\mathrm{a}}$ & II \\
\hline Chondria $^{\mathrm{a}}$ & II \\
\hline Cladophora & II \\
\hline Codium & II \\
\hline Colpomenia & II \\
\hline Corallina & I \\
\hline Cystoseira & I \\
\hline Dasya & II \\
\hline Dermatolithon & I \\
\hline Dictyopteris & II \\
\hline Dictyota & II \\
\hline Ectocarpus & II \\
\hline Enteromorpha & II \\
\hline Erithrotrichia & II \\
\hline Flabellia & I \\
\hline Fosliella & I \\
\hline Gelidiella $^{\mathrm{a}}$ & II \\
\hline Gelidium $^{\mathrm{a}}$ & II \\
\hline Gigartina $^{\mathrm{a}}$ & II \\
\hline Gonyotrichum & II \\
\hline Gracilaria $^{\mathrm{a}}$ & II \\
\hline Griffithsia & II \\
\hline Halimeda & I \\
\hline Halopteris $^{\mathrm{a}}$ & II \\
\hline Herposiphonia & II \\
\hline Hypnea $^{\mathrm{a}}$ & II \\
\hline Jania & I \\
\hline Laurencia $^{\mathrm{a}}$ & II \\
\hline Lithothamnion & I \\
\hline Lomentaria $^{\mathrm{a}}$ & II \\
\hline Lophosiphonia & II \\
\hline Padina & I \\
\hline Petalonia & II \\
\hline Peyssonelia & I \\
\hline Polysiphonia & II \\
\hline Pseudochlorodesmis & II \\
\hline Sargassum & I \\
\hline Scytosiphon & II \\
\hline Spermothamnion & II \\
\hline Sphacelaria ${ }^{\mathrm{a}}$ & II \\
\hline Taonia & $\mathrm{I}$ \\
\hline Ulva & II \\
\hline Valonia $^{\mathrm{a}}$ & II \\
\hline
\end{tabular}

Data were adopted from Orfanidis et al. (2001). ${ }^{a}$ Indicate provisional classification. 


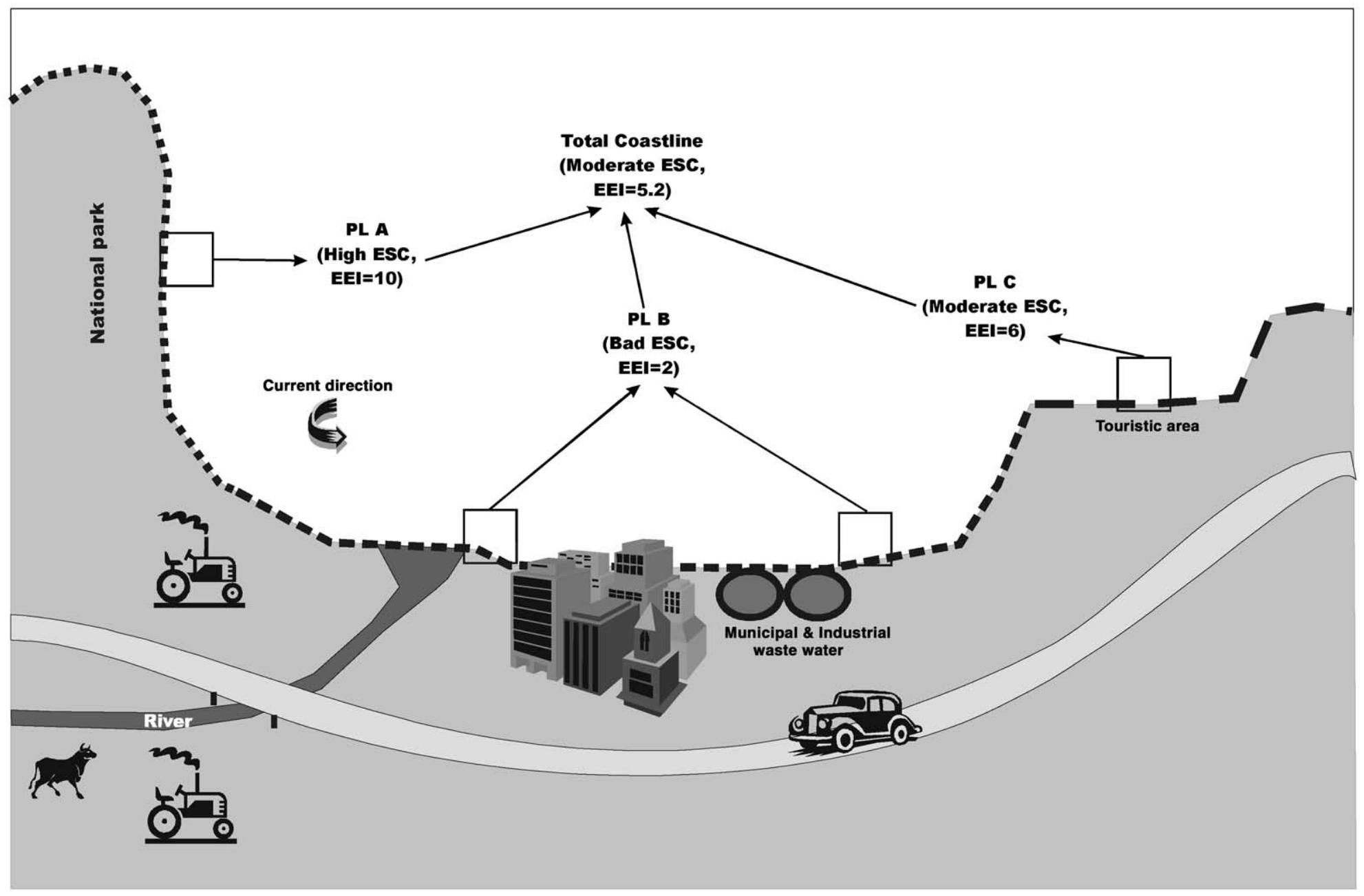

Fig. 1. A hypothetical coastal ecosystem including coastlines (PL) of different ESCs. Rectangles show PL representative permanent vegetative areas (cells) for sampling. 
Table 2

Estimation of EEI and the equivalent ESCs from the abundance of ESGs

\begin{tabular}{lllll}
\hline $\begin{array}{l}\text { Mean coverage of } \\
\text { ESG I (\%) }\end{array}$ & $\begin{array}{l}\text { Mean coverage of } \\
\text { ESG II (\%) }\end{array}$ & ESC & EEI at PP or PL & $\begin{array}{l}\text { Spatial scale weighted EEI } \\
\text { and equivalent ESCs }\end{array}$ \\
\hline $0-30$ & $0-30$ & Moderate & 6 & $\leq 6$ to $>4=$ Moderate \\
& $>30-60$ & Low & 4 & $\leq 4$ to $>2=$ Low \\
& $>60$ & Bad & 2 & Bad \\
$>30-60$ & $0-30$ & Good & 8 & $\leq 8$ to $>6=$ Good \\
& $>30-60$ & Moderate & 6 & $\leq 6$ to $>4=$ Moderate \\
& $>60$ & Low & 4 & $\leq 4$ to $>2=$ Low \\
$>60$ & $0-30$ & High & 10 & $\leq 10$ to $>8=$ High \\
& $>30-60$ & Good & 8 & $\leq 8$ to $>6=$ Good \\
& $>60$ & Moderate & 6 & $\leq 6$ to $>4=$ Moderate \\
\hline
\end{tabular}

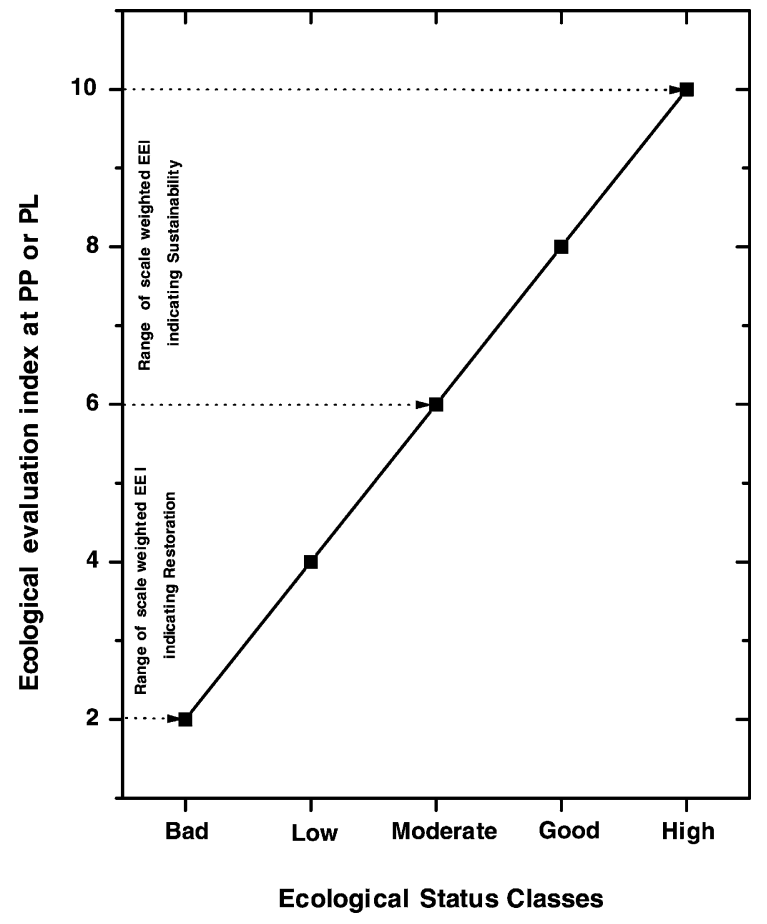

Fig. 2. The linear relationship between EEI and the ESC. EEI ranges for restoration and sustainability.

\section{Example}

A hypothetical coastal water system (CWS) is divided in three ecologically uniform PLs (A-C) covering 30, 50 and $20 \%$ of the total coastline, respectively (Fig. 1). The mean absolute coverage (\%) of ESGs I and II of samples in the PL A was 140 and 20, respectively. This corresponds to the high ESC and to
EEI 10. The mean absolute coverage (\%) of ESGs I and II of samples in the PL B was 10 and 90, respectively. This corresponds to the bad ESC and to EEI 2. The mean absolute coverage (\%) of ESGs I and II of samples in the PL C was 45 and 40, respectively. This corresponds to the moderate ESC and to EEI 6. The EEI of the whole CWS is following: $\mathrm{EEI}=$ $(10 \times 0.3)+(2 \times 0.5)+(6 \times 0.2)=3+1+1.2=5.2$, which corresponds to the moderate ESC.

\section{Discussion}

The EEI (Table 2) quantifies shifts in transitional and coastal waters from pristine to degraded state, which is dominated by opportunistic species (Odum, 1985). The latter is a well-known pattern also from the marine environment (Regier and Corwell, 1972; Duarte, 1995; Harlin, 1995; Schramm, 1999), irrespectively of having one or multiple stable equilibrium states (see Scheffer et al., 2001). Coral reefs, for example, shift due to nutrient loading and over-fishing to an alternative stable state, which is characterized by the dominance of fleshy opportunistic macroalgae (McCook, 1999). Similarly, Scheffer et al. (1993) recognizes two alternative stable stages in lakes, the pristine (oligotrophic) state with clear water and rich submerged vegetation and the degraded (eutrophic) with high turbidity and phytoplankton biomass. In intermediate nutrient levels the last two equilibria alternate and their organisms coexist.

The EEI is based on marine benthic macrophytes inhabiting sediment (roots of seagrasses) as well as water column (seaweeds and leaves of seagrasses) of 


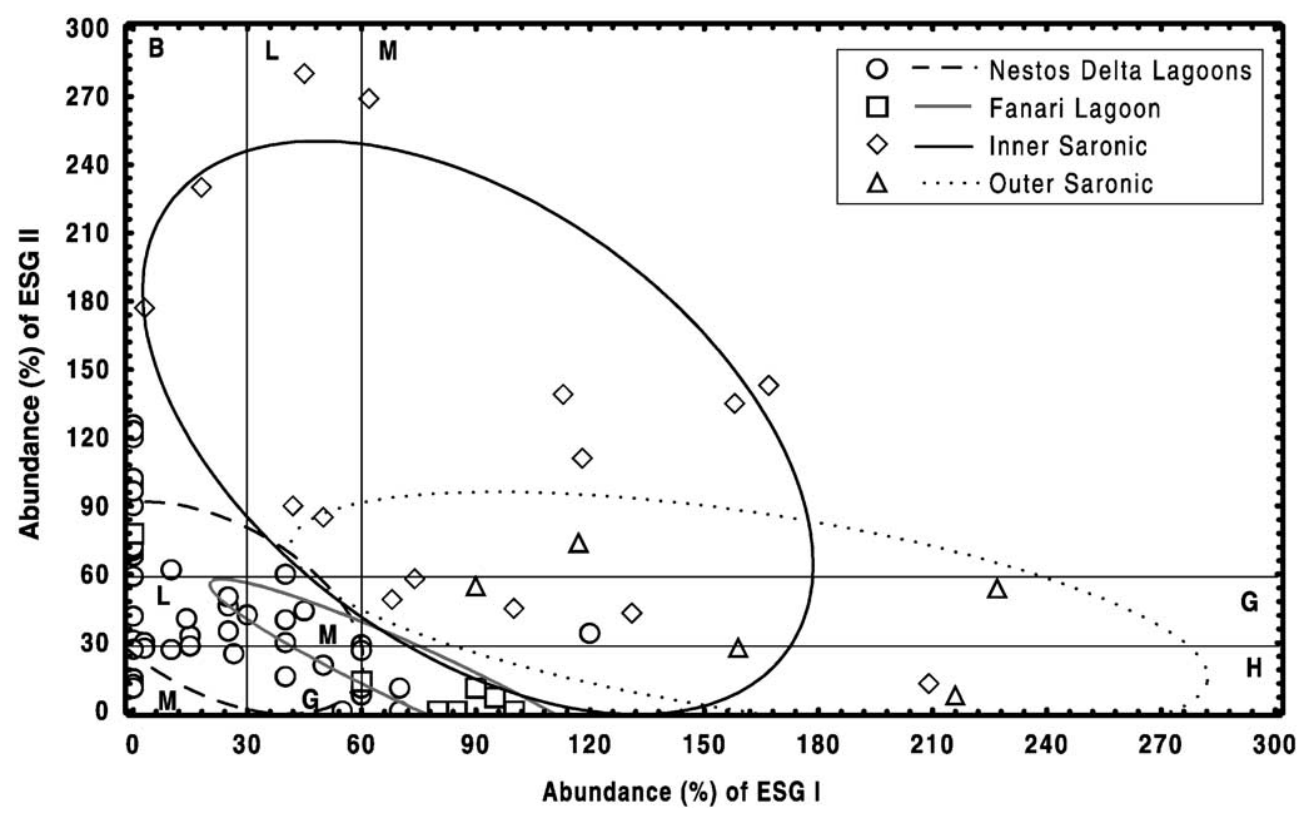

Fig. 3. A categorized scatterplot of abundance (\%) of ESGs at different transitional (Delta Nestos and Fanari Lagoons) and coastal (inner and outer Saronic Gulf) ecosystems in Greece. For raw data see Orfanidis et al. (2001). Elliptic areas predict $x, y$ values with a $60 \%$ coefficient. The vertical and horizontal lines divide the scatterplot in five ESCs (B, bad; L, low; M, moderate; G, good; H, high).

transitional and coastal waters. Therefore, it provides a unifying framework (Fig. 3) for an integrated evaluation of ecological status. Because it is based on seasonal sampling reflects the mean of environmental conditions. Seasonal sampling is important because: (1) brackish and polluted waters are unpredictable environments with temporal environmental and thus community changes (Fig. 3), and (2) several opportunistic species existed also in pristine ecosystems by adequate seasonal timing to take full advantages of environmental resources. Examples are the growth of Scytosiphon in pristine Helgoland, Germany coasts (Bartsch, 1987) and of Cladophora species in oligotrophic Mediterranean coasts (personal observation) during spring.

Marine benthic macrophytes although including evolutionary different groups of plants, such as seaweeds and seagrasses, show adaptive morphologies. For seaweeds Littler and Littler (1980) have proposed a functional-form model, which was tested and verified experimentally: the functional characteristics of plants, such as photosynthesis, nutrient uptake, and grazer susceptibility, are related to morphology and surface area : volume ratios (Littler and Littler,
1980, 1984; Littler and Arnold, 1982). Orfanidis et al. (2001) have included seagrasses in this model and then used it to divide marine benthic macrophytes in two different ecological groups, the late-successional (perennials, ESG I) and the opportunistic (annuals, ESG II). Because the functional groups include considerable variation of forms-functional responses (Littler and Littler, 1984) the classification of certain seaweed genera, e.g. coarsely branched, into ESGs (Table 1) should be regarded as provisional remaining an experimental verification.

The main implication of multiple ecosystem stable states insight is that efforts to reduce the risk of unwanted state shifts due to stochastic events should focus on the gradual changes affecting the ecological resilience of the ecosystem (Holling, 1973) rather than to control disturbances. Ecological resilience typically depends on slowly changing variables, e.g. nutrient, biodiversity, the biomass of long-lived organisms (Scheffer et al., 2001). The latter indicates the relation of EEI to the ecosystem resilience, which is today a key concept in ecological research (Gunderson, 2000). Using EEI one can identify two distinct ecological states, the pristine and the degraded. Both 
states can be resilient (Carpenter et al., 2001). When EEI approaches 10 the resilience of the pristine state became maximum and of the degraded state 0 . The opposite happens when EEI approaches 2.

The EEI is based on absolute abundance of the ESGs and it is closely related to ecosystem function or processes, e.g. nutrient cycling (Asmus and Asmus, 2000), and fish production (Fonseca et al., 1996a,b). High values of EEI indicate the existence of high ecologically and economically valued communities (Costanza et al., 1997).

The EEI was designed to: (1) cover the prerequisites of European WFD, which will be the operational tool setting the objectives for water protection well in Europe (EEC, 2000), and (2) offer to water managers worldwide a tool for comparing, ranking and setting management priorities at different spatial levels, e.g. regional, national, international. EEI values higher than 6 indicate sustainable ecosystems of good or high ESC, whereas EEI values lower than 6 indicate that the ecosystems should be restored to a higher ESC (Fig. 2).

An exact identification of the limits of the ESGs and the ESC could improve the EEI accuracy, whereas the identification of relations of ESGs to different kinds of stress/disturbance or ecosystem states by using a hierarchical approach to the analysis of trait sets (Lavorel et al., 1997) could improve the EEI specification.

\section{References}

Asmus, H., Asmus, R., 2000. Material exchange and food web of seagrass beds in the Sylt-Røm $\varnothing$ bight: how significant are community changes at the ecosystem level? Helgoland Mar. Res. 54, 137-150.

Bartsch (tom Dieck), I., 1987. Temperature tolerance and daylength effects in isolates of Scytosiphon lomentaria (Phaeophyceae) of the North Atlantic and Pacific Ocean. Helgolaender Meeresuntersuchungen 41, 307-321.

Bricker, S.B., Clement, C.G., Pirhalla, D.E., Orlando, S.P., Farrow, D.R.G., 1999. National estuarine eutrophication assessment: effects of nutrient enrichment in the nation's estuaries. NOAA, National Ocean Service, Special Projects Office and the National Centers for Coastal Ocean Science, Silver Spring, MD, p. 71 .

Carpenter, S., Walker, B., Anderies, M.J., Abel, N., 2001. From metaphor to measurement: resilience of what to what? Ecosystems 4, 765-781.

Costanza, R., d'Arge, R., de Groot, R., Farber, S., Grasso, M., Hannon, B., Limburg, K., Naeem, S., O’ Neill, R.V., Paruelo,
J., Raskin, R.G., Sutton, P., van den Belt, M., 1997. The value of the world's ecosystem services and natural capital. Nature 387, 253-260.

Crowe, T.P., Thomson, R.C., Bray, S., Hawking, S.J., 2000. Impacts of anthropogenic stress on rocky intertidal communities. J. Aquat. Ecosyst. Stress Recovery 7, 273-297.

Crooks, S., Turner, R.K., 1999. Intergraded coastal management: sustaining estuarine natural resources. In: Nedwell, D.B., Raffaelli, D.G. (Eds.), Estuaries: Advances in Ecological Research, vol. 29. Academic Press, New York, pp. 241-289.

Dauer, D.M., 1993. Biological criteria, environmental health and estuarine macrobenthic community structure. Mar. Pollut. Bull. 26 (5), 249-257.

Duarte, C.M., 1995. Submerged aquatic vegetation in relation to different nutrient regimes. Ophelia 41, 87-112.

EEC, 2000. Directive 2000/60/EC of the European Parliament and of the Council of 23 October 2000 establishing a framework for Community action in the field of water policy. Off. J. Eur. Communities 43, 1-72.

Fonseca, M.S., Kenworthy, W.J., Courtney, F.X., 1996a. Development of planted seagrass beds in Tampa Bay, Florida, U.S.A. I. Plant components. Mar. Ecol. Prog. Ser. 132, 127139.

Fonseca, M.S., Meyer, D.L., Hall, M.O., 1996b. Development of planted seagrass beds in Tampa Bay, Florida, U.S.A. II. Faunal components. Mar. Ecol. Prog. Ser. 132, 141-156.

Gibson, G.R., Bowman, M.L., Gerritsen, J., Snyder, B.D., 2000. Estuarine and Coastal Marine Waters: Bioassessment and Biocriteria Technical Guidance. EPA 822-B-00-024. U.S. Environmental Protection Agency, Office of Water, Washington, DC.

Gunderson, L.H., 2000. Ecological resilience-in theory and application. Ann. Rev. Ecol. Syst. 31, 425-439.

Harlin, M.M., 1995. Changes in major plant groups following nutrient enrichment. In: Mc Comb, A.J. (Ed.), Eutrophic Shallow Estuaries and Lagoons. Institute for Environmental Science, Murdoch University, Murdoch, Australia. CRC Press, Boca Raton, pp. 173-187.

Holling, C.S., 1973. Resilience and stability of ecological systems. Ann. Rev. Ecol. Syst. 4, 1-23.

Jones, C.G., Lawton, J.H., Shachak, M., 1994. Organisms as ecosystem engineers. Oikos 69, 373-386.

Lavorel, S., McIntyre, S., Landsberg, J., Forbes, T.D.A., 1997. Plant functional classifications: from general groups to specific groups based on response to disturbance. Trends Ecol. Evol. 12, 474-478.

Littler, M.M., Arnold, K.E., 1982. Primary productivity of marine macroalgal functional-forms groups from southwestern North America. J. Phycol. 18, 307-311.

Littler, M.M., Littler, D.S., 1980. The evolution of thallus form and survival strategies in benthic marine macroalgae: field and laboratory tests of a functional form model. Am. Nat. 116, $25-44$.

Littler, M.M., Littler, D.S., 1984. Relationships between macroalgal functional form groups and substrata stability in a subtropical rocky-intertidal system. J. Exp. Mar. Biol. Ecol. 74, 13-34. 
Maler, K.G., 2000. Development, ecological resources and their management. A study of complex dynamic systems. Eur. Econ. Rev. 44, 645-665.

McCook, L.J., 1999. Macroalgae, nutrients and phase shifts on coral reefs: scientific issues and management consequences for Great Barrier Reef. Coral Reefs 18, 357-367.

McRoy, C.P., Lloyd, D.S., 1981. Comparative function and stability of macrophyte-based ecosystems. In: Longhurst, A.R. (Ed.), Analysis of Marine Ecosystems. Academic Press, New York, pp. 473-489.

Odum, E.P., 1985. Trends expected in stressed ecosystems. BioScience 35, 419-422.

Orfanidis, S., Panayotidis, P., Stamatis, N., 2001. Ecological evaluation of transitional and coastal waters: a marine benthic macrophytes-based model. Mediterranean Mar. Res. 2 (2), 4565 .
Regier, H.A., Corwell, E.B., 1972. Applications of ecosystem theory, succession, diversity, stability, stress and conservation. Biol. Conserv. 4 (2), 83-88.

Schramm, W., 1999. Factors influencing seaweed responses to eutrophication: some results from EU-project EUMAC. J. Appl. Phycol. 11 (1), 69-78.

Scheffer, M., Hosper, S.H., Meijer, M.L., Moss, B., 1993. Alternative equilibria in shallow lakes. Trends Ecol. Evol. 8, 275-279.

Scheffer, M., Carpenter, S., Foley, J.A., Folke, C., Walker, B., 2001. Catastrophic shifts in ecosystems. Nature 413, 591-596.

Steneck, R.S., Watling, L., 1982. Feeding capabilities and limitation of herbivorous molluscs: a functional group approach. Mar. Biol. 68, 299-319. 